\title{
THE IMPACT OF TEACHING GEOMETRIC LOCUS PROBLEMS IN A COMPUTER-ASSISTED ENVIRONMENT ON THE METACOGNITIVE AWARENESS OF PRESERVICE TEACHERS
}

\author{
Serdal Baltaci
}

\begin{abstract}
In this study, it is expected that the GeoGebra contributes to the declarative knowledge, procedural knowledge, conditional knowledge, planning, monitoring, evaluation, debugging, and information management sub-dimensions of the metacognitive awareness. In this study, an experimental research technique, which was based on the pre- and post-tests scores of the participants, of the quantitative research method was used in order to investigate the development of preservice middle school teachers' metacognitive awareness. Forty six preservice teachers who have enrolled to the department of elementary school mathematics at the faculty of education participated in the study. The preservice teachers, 25 female and 21 male, were attending to the same class. In this study, likert-type Metacognitive Awareness Inventory consisting of 52 items was used as a data collection tool. The collected data were analyzed using the SPSS 21.0 statistical package. As a result of the study, the findings suggest that teaching geometric locus in this kind of a setting is generally effective. When the collected data examined, it appeared that there was not a statistically significant difference on the Debugging sub-dimension of metacognitive awareness in which the effect size was small. In the remaining sub-dimensions, the difference was statistically significant.
\end{abstract}

Key words: metacognition, geogebra dynamic mathematics software, geometric locus, preservice mathematics teachers.

\section{Introduction}

Recent studies emphasize that students should actively participate in the learning process and question themselves during this active participation. Metacognition is one of the theories that enable learners to connect new knowledge to the knowledge they have, to observe their own learning, and to internalize new knowledge by using them in new areas (Victor, 2004). Although, metacognition was first introduced by Flavell (1998), its history theoretically goes back to earlier years. Metacognition, which is defined in different ways by many researchers, is defined by Flavell (1979) as the knowledge that one obtains from her own cognitive experiences. Similarly, metacognition is one's thinking about his own thinking and learning processes (Garner, 1987; Welton \& Mallan, 1999). Furthermore, Gunstone and Mitchell (1998) define metacognition as a person's activation of maintaining and planning processes of her thinking practices. Therefore, metacognition involves the process of individuals' thoughts about the thinking and learning mechanisms and combining these thoughts with their experiences. Individuals organize and evaluate their own knowledge through metacognition.

Polincsar (1986) used football metaphor to explain metacognition concept in the following way: There are a number of strategies and game plans that a good football team can use during the game, but knowing these strategies theoretically is not important. A good team chooses the best strategy considering the team's purposes, strengths and weaknesses, and the strengths and weakness of its opponents, but that may not be enough. A good team constantly evaluates the appropriateness of a strategy during a game, and if not, chooses another strategy. As in the football metaphor, students also have strategies to meet their learning needs, but this is not enough for students. Students choose a strategy based on the goal of a lesson, obstacles that they face, and their own strengths and weaknesses.

Received: 5 March 2018, accepted 12 July 2018.

Cite as: Baltaci, S. (2018). The impact of teaching geometric locus problems in a computer-assisted environment on the metacognitive awareness of preservice teachers. Acta Didactica Napocensia, 11(2), 121-134, DOI: 10.24193/adn.11.2.10. 
Next, they look at whether the strategy they have chosen has helped them in their learning, and if not, they choose a new strategy. It is important for a learner to generate her awareness about the learning processes to sustain the success of these processes (Doğan, 2013).

In order to generate this awareness, a student should be able to question, make plans, use her reasoning skills effectively, and evaluate the learning process (Çakıroğlu, 2007; Tunca \& Alkın-Şahin, 2014). This situation, which can be described as metacognitive awareness, is defined as trying to understand what the teacher wants during the instruction and noticing she understands something or not (Karakelle \& Saraç, 2007). In other words, metacognitive awareness can be defined as the knowledge that individuals have about their own metacognitions. Ylldirım (2010) defined metacognitive awareness as an individual's awareness about her learning system. Looking at these definitions, the question "can metacognitive awareness develop?" comes to mind since there is a tendency in educational studies on developing students' metacognitive awareness (Douville \& Pugalee, 2003).

Everson and Tabias (1998) stated that students who equipped with effective metacognitive skills will correctly assess their knowledge, monitor their learning, update their knowledge, and make effective plans for new learning topics. Furthermore, it is important for individuals to have knowledge about their own learning and cognitive processes or to develop awareness in this context (Deseote, Roeyers \& Buysse, 2001; Kuiper, 2002; Şen, 2012). Schunk (1989) noted that teachers with clearer metacognitive awareness would increase their chances of developing students' cognitive and metacognitive skills. According to the research on metacognition instruction, these skills can be taught to the students directly or indirectly (Toney, 2000; Paris \& Winograd, 1990). In addition, as stated by Hacker (1998), metacognition instruction facilitates students' learning. Because the metacognition levels of teachers are an important factor in the development of students' metacognitive skills, it is important to examine the development of these awareness of the preservice mathematics teachers. Therefore, teacher preparation programs could provide more benefits on preservice teachers' (PSTs') teaching if these teachers were instructed about metacognitive awareness and their comprehension of this concept is satisfied.

The effect of teaching on the acquisition of metacognitive skills is much more than the influence of maturity alone (Senemoğlu, 1997). Learners' ability to use metacognition efficiently in the processes of decision-making, in determining the appropriate strategy, and ultimately in evaluation-analysis, can be achieved in a learning environment where they can experience these processes. Smith, Ford and Kozlowski (1997) stated that learners' metacognitions may be developed by preparing environments in which they can actively participate in the learning process. On the other hand, Jones, Farquhar and Surry (1995) noted that a student's active participation in the learning process can be enhanced to the extent to which her metacognitive awareness can be improved. Hence, teachers can improve students' metacognitions by creating learning environments in which students can participate effectively in learning processes. By creating learning environments for increasing students' metacognitive knowledge and skills, their success can be further enhanced. Computer-aided learning environments can be used in overcoming such situations. Studies showed the effectiveness of computer-aided learning environments on increasing students' metacognitive knowledge and skills (Gama, 2001; Howard, McGee, Hong \& Shia, 2000; Mckay, 1999; Volet, 1991). Therefore, the potential of computer-aided software can be used in learning environments for the development of metacognition.

With computer-aided software, students perceive mathematics as a game enjoying what she has been doing and being aware of a large part of the learning role rest in her shoulders rather than abstractly perceiving mathematics as calculations and symbolic expressions (Olive, 2002). Hazzan and Goldenberg (1997) stated that dynamic software, which is the most important of computer-aided software, allow students to concentrate more on abstract structures. One of these software, the GeoGebra, can be used with many features other than the features found in other software. The GeoGebra software is an important part of teaching mathematics with its ease of use, diverse versatility, language options, and combining both the properties of computer algebra systems (CAS) and the features of dynamic geometry software (DGS) (Hohenwarter \& Jones, 2007). GeoGebra provides fast transitions between representations by its algebra, drawing board, calculator chart, statistical calculations window, and two-dimensional window features, which enable production of mathematical symbols and graphics and transfer of these symbols and graphics to tables in a dynamic process 
(Dikovich, 2009; Hohenwarter \& Jones, 2007). Thus, how these features of GeoGebra can be used in the development of metacognitive awareness of PSTs has become an important research topic. The concept of geometric locus can be considered as a worthy study topic that can be investigated using GeoGebra because many cognitive processes, estimating geometric locus and evaluating own knowledge by comparing estimations with each other, can be developed using the "trace" and "geometric locus" functions (Baltaci, 2014).

The geometric locus, which is one of the analytical geometry concepts, was first seen in the curricula of developed countries a century ago, especially in the German curriculum (Gülk1lık, 2008). Because the geometric locus is an abstract concept, its way of reasoning, and being able to make different estimations, it has not given enough attention and had a symbolic place in the mathematics curriculum (Botana ve Valcarce, 2003; Pekdemir, 2004).

Geometric locus defined as a point's, which moves under some specific conditions, trajectory path (Botana and Valcarce, 2003; Cha and Noss, 2001) or set of points and lines that determined by special mathematical conditions or ensuring some special conditions (Gorghiu, Puana and Gorghiu, 2009). The literature suggest that dynamic geometry software have an important potential on showing geometric locus of an object (Frank, 2010; Güven, 2002; Güven 2008; Güven \& Karataş, 2009; Jahn, 2002; Real \& Leung, 2006).

Geometric locus concept becomes clearer by the help of "Geometric Locus" and "Trace" features of this type of software (Baltaci, 2014; Cha \& Noss, 2004; Güven \& Karataş, 2009; Schumann \& Green, 2001). Using dynamic software in classroom settings, one can contribute to students' learning by involving them directly in the teaching process and letting them work within a context (Baltaci, 2014; Baltaci \& Baki, 2016).

The geometric locus is at one of the leading topics in which PSTs have difficulties (Gorghiu et al., 2009; Güven \& Karataş, 2009; Gülkılık, 2008; Jahn, 2002; Real \& Leung, 2006). PSTs who have incomplete knowledge on this topic encounter various difficulties while solving problems related to the geometric locus (Baltaci, 2014; Gorghiu et al., 2009; Gülkılık, 2008; Güven \& Karataş, 2009) because this concept requires abstract reasoning and moving some geometry objects in mind.

Therefore, it is very difficult to visualize geometric locus problems in traditional environments (Güven $\&$ Karataş, 2009). These difficulties can be overcome with the various icons of the GeoGebra software. The GeoGebra software is an effective tool in teaching geometric locus concept and offers new opportunities to solve such problems (Baki, Çekmez \& Kösa, 2009; Baltaci, 2014; Baltaci, Yildiz \& Kösa, 2015). So far, the advantages of teaching the geometric locus concept in computer-aided environments were explained. Now, the readers may ask the following question: "Why was the geometric locus concept used in explaining metacognitive awareness?" Metacognition involves the ability of an individual's prediction, planning, monitoring, and evaluating their own mental activities (Brown, 1980). The GeoGebra software supports the concept of geometric locus as well as estimation process, explanations of estimations, geometrical places modeled in the GeoGebra display both in the paper-pencil environment and evaluation of results after viewing these concepts on the GeoGebra screen, and correcting mistakes that students made. In addition, it is expected that the GeoGebra contributes to the declarative knowledge, procedural knowledge, conditional knowledge, planning, monitoring, evaluation, debugging, and information management sub-dimensions of the metacognitive awareness.

Metacognition is a teachable skill, and individuals are not born with this process of reasoning (Hall \& Myers, 1998). Many studies have shown that metacognition can be successfully developed, especially in the field of mathematics (Kramarski \& Mevarech, 2003; Lucangeli \& Cornoldi, 1997). The literature on metacognition showed that some researchers focused on the relationship between students' metacognition and their problem solving skills and mathematical achievements (Baltaci, Yildiz \& Özcakir, 2016; Deseoete et al., 2001; Kramarski, 2008; Yildiz, Baltaci \& Güven, 2011), focused on the development of metacognition (Küçük-Özcan, 2000; Schoenfeld, 1987; Volet, 1991; Y1ldız \& Ergin, 2012), and focused on the change in individuals' metacognition by conducting experimental teaching methods (Blank, 2000; Kramarski, Zemira \& Arami, 2002). On the other hand, studies on the geometric locus concept pointed out that by the use of dynamic geometry software, those researchers were able to 
observe students' intuitive reasoning, and so they were able to emphasize the importance of teaching this concept, which is usually neglected in the traditional teaching settings (Baki et al., 2009; Güven, 2002; Güven 2008; Güven \& Karataş, 2009; Jahn, 2002; Real \& Leung, 2006). In this study, the effect of preservice middle school teachers' learning processes of the geometric locus concept, which is one of the analytic geometry concepts, on their metacognitive awareness is examined with the use of GeoGebra dynamic software. Moreover, unlike most researchers, this effect will be studied in all subcomponents of metacognitive awareness that will eventually provide important contributions to the field. Within this scope, the following research questions were investigated:

1. How does teaching geometric locus problems in a GeoGebra software-assisted environment effect preservice teachers' metacognitive awareness?

2. Does teaching geometric locus problems in the GeoGebra software-assisted environment provoke a significant relationship between preservice teachers' metacognitive awareness and their gender?

3. Does teaching geometric locus problems in the GeoGebra software-assisted environment provoke a significant relationship between preservice teachers' metacognitive awareness and their academic achievements?

4. Does teaching geometric locus problems in the GeoGebra software-assisted environment provoke a significant relationship between preservice teachers' metacognitive awareness and their teaching experiences?

\section{Method}

The following section covers the research model, design of the research, research group, data collection, and data analysis.

\section{1. The Model of the Study}

In this study, an experimental research technique, which was based on the pre- and post-tests scores of the participants, of the quantitative research method was used in order to investigate the development of preservice middle school teachers' metacognitive awareness. This study used an experimental method without having a control group since, except for a few universities, the mathematics education courses in the elementary mathematics education departments in Turkey are carried out in single groups due to the limited quota.

\section{2. The Design of the Study}

The design of the research takes place in two stages. These stages are as follows:

\section{2. 1. Preparation Stage}

When examined the related literature, students have been found to be successful in the analytic geometry concepts if a well-organized learning setting is designed. Hence, worksheets that affect the learning setting were initially prepared through analyzing various publications on metacognition and analytical geometry. Worksheets included guidelines about how PSTs required to use the GeoGebra software during the process of discovery on related analytical geometry concepts. Next, assessments carried out by two domain experts and the necessary corrections have been made.

\section{2. 1. Implementation Stage}

A pilot study performed after checking the compatibility of the data collection tools. Next, at the initial phase of the implementation stage, the PSTs were given a Metacognitive Awareness Inventory. Later, two-person groups formed for the dynamic software-aided learning settings. While forming those groups, coordination and level of success between the members of each group have been taken into account. A total of 23 groups have been created.

Taking courses on basic Information and Communication Technology (ICT) skills during the first year of their undergraduate education, the preservice mathematics teachers began interacting with the GeoGebra software in two courses (General Mathematics, Geometry). At the second year, GeoGebra is 
used only when needed for presentation purposes in Calculus I course. In addition, the PSTs were asked to use the GeoGebra software in their exams or to answer the presented questions. Hence, all participants were trained about using GeoGebra and preparing activities using it. The PSTs already had skills that were needed to construct the geometric locus situations on worksheets. Furthermore, their mathematics competency levels were sufficient enough, and they had positive attitudes towards mathematics.

The implementation stage took 6 weeks, and a total of six worksheets used in this stage. The course included geometric locus. The purpose in the course was to use the GeoGebra software as a tool to acquire the required information from the PSTs. For example, in one of the worksheets, the problem "Where is the geometric locus of the tangents that were drawn from a fixed point, A, to the circles that had $\mathrm{O}$ as the central-fixed point in the plane?" was asked. During the answer process, the PSTs made predictions about possible solution situations by discussing with their group mates. They then tried to explain their predictions on a paper.

For instance, for the problem above, first, the PSTs tried to explain their predictions primarily using paper-pencil and by marking two points, a circle arc and circle predictions. Afterwards, they tried to create desired drawings on the GeoGebra screen by which they were able to compare their predictions using the utilities of the software. For example, a screen shot from the work of a group who drew twopoints and a circle arc as their prediction in a paper-pencil setting (Figure 1) and a screen shot from another group creating their circle prediction on the GeoGebra screen (Figure 2) are given as follows:
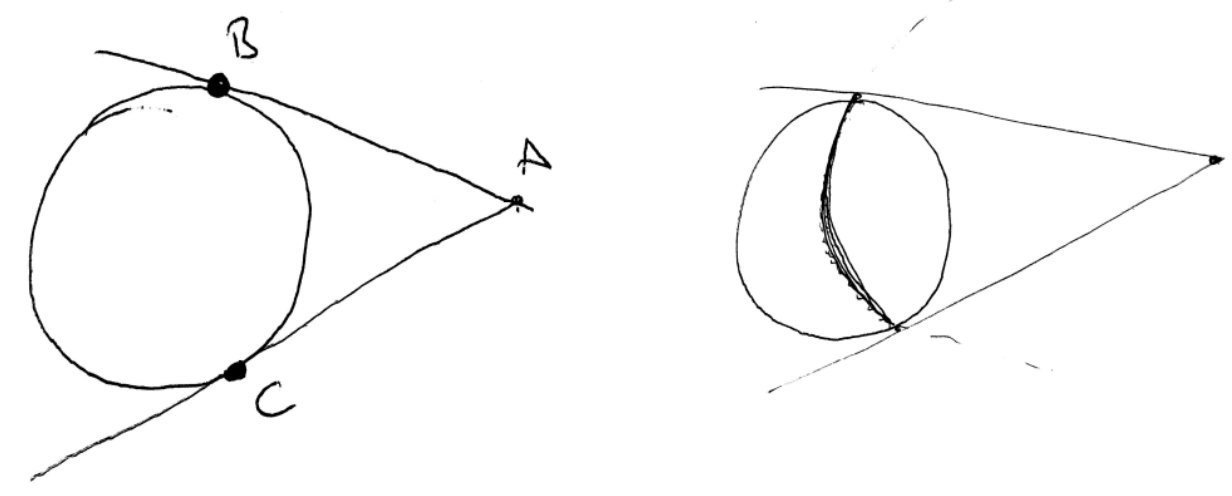

Figure 1. Two preservice teachers' predictions in a paper-pencil setting.

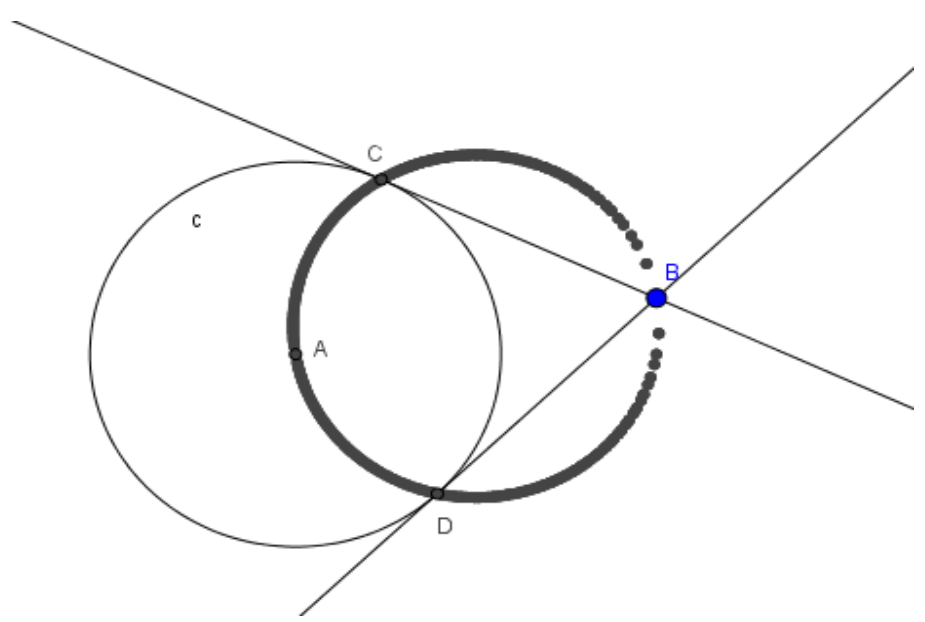

Figure 2. Two preservice teachers' predictions on the GeoGebra Screen. 
As stated above, during the 6 weeks of implementation stage, geometric locus problems were provided to the PSTs using worksheets, and the responses were analyzed. At the end of the implementation stage, the Metacognitive Awareness Inventory was repeated in order to provide answers to the research questions.

\section{3. Participants}

Forty six PSTs who have enrolled to the department of elementary school mathematics at the faculty of education participated in the study. The PTSs, 25 female and 21 male, were attending to the same class.

\section{4. The Data Collection Tools}

In this study, Likert-type Metacognitive Awareness Inventory consisting of 52 items was used as a data collection tool. Developed by Schraw and Dennison (1994), this inventory is adapted to Turkish by Akın, Abacı and Çetin (2007). In their study, Schraw and Dennison (1994) found the reliability coefficient of this inventory to be 0.93 . In the Turkish adaptation, Akın et al. (2007) found the Cronbach alpha reliability of the Metacognitive Awareness Inventory to be 0.95. Turk (2011) stated that for subscales this value changed between 0.93 and 0.98. The items in the Metacognitive Awareness Inventory had a 5-point likert-type rating system: (1) never, (2) sometimes wrong, (3) neutral, (4) sometimes true, and (5) always true. The distribution of 52 items according to subscales was as follows: Declarative Knowledge: Item 5, 10, 12, 17, 16, 32, 20, and 46; Procedural Knowledge: Item 33, 14, 27 , and 3; Conditional Knowledge: Item 26, 29, 35, 15, and 18; Planning: Item 42, 6, 4, 45, 8, 23, and 22; Monitoring: Item 49, 11, 1, 2, 21, 28, 34, and 41; Evaluation: Item 36, 24, 19, 7, 50, and 38; Debugging: Item 25, 51, 40, 44, and 52; and Information Management; Item 37, 31, 47, 9, 43, 13, 39, 30, and 48. There was not negative items in this inventory. While the highest score that can be taken from the inventory was 260 , the lowest score was 52 . A conclusion could be reached about the metacognitive awareness level of an individual by dividing the total score that she obtained from the inventory by the number of items (52). Akın et al. (2007) stated that individuals who receive less than 2.5 points from the Metacognitive Awareness Inventory have lower metacognitive awareness, and those who receive 2.5 points and above have higher metacognitive awareness.

\section{5. Analysis of the Data}

The collected data were analyzed using the SPSS 21.0 statistical package. The t-test was used to compare metacognition awareness and subscale scores of the PST with pre- and post-test scores and to compare differences among post- and pre-test scores with the gender and experience. In addition, the effect size was measured with Cohen d. Furthermore, the one-way analysis of variance (ANOVA) was used for investigating the relationship between the average score and scores that obtained from differences among post- and pre-test points.

\section{Findings}

In this section, the quantitative data obtained from the PSTs were discussed separately in order to clarify four research questions. The t-test and effect-size results for pre and post-test average scores on the PSTs' metacognitive awareness and its sub-dimensions are presented in Table 1. 
The impact of teaching geometric locus problems in a computer-assisted environment on the metacognitive awareness of preservice teachers

Table 1. The t-test and effect-size results for pre and post-test

\begin{tabular}{|c|c|c|c|c|c|c|c|c|}
\hline \multicolumn{9}{|c|}{ Group Statistics } \\
\hline & Group & $\mathrm{N}$ & Mean & $\begin{array}{c}\text { Std. } \\
\text { Deviation }\end{array}$ & $\mathrm{t}$ & $\mathrm{df}$ & Sig. (2-tailed) & Cohen's $d$ \\
\hline \multirow[t]{2}{*}{ Overall } & Pretest & \multirow[b]{2}{*}{46} & 3,0974 & ,37615 & \multirow[b]{2}{*}{14,071} & \multirow[b]{2}{*}{45} & \multirow[b]{2}{*}{,000 } & \multirow[t]{2}{*}{0,172753} \\
\hline & Posttest & & 3,7019 & 32156 & & & & \\
\hline \multirow{2}{*}{$\begin{array}{l}\text { Declarative } \\
\text { Knowledge }\end{array}$} & Pretest & \multirow{2}{*}{46} & 2,7745 & ,46519 & \multirow{2}{*}{16,569} & \multirow{2}{*}{45} & \multirow{2}{*}{,000 } & \multirow[t]{2}{*}{0,256194} \\
\hline & Posttest & & 3,9212 & ,42927 & & & & \\
\hline \multirow{2}{*}{$\begin{array}{l}\text { Procedural } \\
\text { Knowledge }\end{array}$} & Pretest & \multirow{2}{*}{46} & 2,8587 & ,43986 & \multirow{2}{*}{11,667} & \multirow{2}{*}{45} & \multirow{2}{*}{,000 } & \multirow[t]{2}{*}{0,203846} \\
\hline & Posttest & & 3,7500 & ,43461 & & & & \\
\hline \multirow{2}{*}{$\begin{array}{l}\text { Conditional } \\
\text { Knowledge }\end{array}$} & Pretest & \multirow{2}{*}{46} & 3,5739 & ,45335 & \multirow{2}{*}{$-5,119$} & \multirow{2}{*}{45} & \multirow{2}{*}{, 000} & \multirow[t]{2}{*}{0,102833} \\
\hline & Posttest & & 3,1739 &, 31158 & & & & \\
\hline \multirow[t]{2}{*}{ Planning } & Pretest & \multirow{2}{*}{46} & 3,2826 & 38508 & \multirow{2}{*}{9,030} & \multirow{2}{*}{45} & \multirow{2}{*}{,000 } & \multirow[t]{2}{*}{0,117936} \\
\hline & Posttest & & 3,7453 & ,39945 & & & & \\
\hline \multirow[t]{2}{*}{ Monitoring } & Pretest & \multirow{2}{*}{46} & 2,7500 & ,47507 & \multirow{2}{*}{14,676} & \multirow{2}{*}{45} & $0 \cap 0 \Omega$ & 0,250701 \\
\hline & Posttest & & 3,9049 & ,44580 & & & , & \\
\hline Information & Pretest & 46 & 3,2609 & ,47961 & 9255 & & 000 & 0,129994 \\
\hline Management & Posttest & 46 & 3,8406 & ,40952 & 9,255 & 45 & , & \\
\hline Debugging & Pretest & 16 & 3,2565 &, 58525 & 120 & & 204 & \\
\hline & Posttest & 46 & 3,1478 &, 24380 & $-1,290$ & 45 & , 204 & \\
\hline Evaluation & Pretest & 46 & 3,1594 & 47135 & 8457 & 15 & 000 & 0,125336 \\
\hline & Posttest & & 3,7500 & ,47108 & $0,4 J 1$ & $4 J$ & , 000 & \\
\hline
\end{tabular}

Table 1 shows that there is not a statistically significant difference between the pre- and post-test scores and Debugging score $[t(45)=-1.290, p>.05]$. For the remaining sub-dimensions and overall average, there are statistically significant differences between the pre- and post-test scores. The absence of a statistically significant difference in the Debugging sub-dimension appears to have a small effect $\left(\eta^{2}=.024247\right)$. The t-test results and effect size analysis for the relationship between the PSTs' average gain scores, which obtained by subtracting pre-test scores from post-test scores, and gender are presented in Table 2.

Table 2. The t-test results and effect size analysis for the relationship between the PSTs' average gain scores and gender

\begin{tabular}{|c|c|c|c|c|c|c|c|c|}
\hline \multicolumn{9}{|c|}{ Group Statistics } \\
\hline & Group & $\mathrm{N}$ & Mean & Std. Deviation & $\mathrm{t}$ & $\mathrm{df}$ & Sig. (2-tailed) & Cohen's $d$ \\
\hline \multirow[t]{2}{*}{ Overall } & Female & 25 & ,5646 & ,31579 & \multirow{2}{*}{$-1,014$} & \multirow{2}{*}{44} & \multirow{2}{*}{, 316} & \\
\hline & \begin{tabular}{|l|} 
Male \\
\end{tabular} & 21 & 6520 & 25886 & & & & \\
\hline \multirow[t]{2}{*}{ Declarative Knowledge } & Female & 25 & 1,0250 & ,32874 & \multirow{2}{*}{$-1,981$} & \multirow{2}{*}{44} & \multirow[b]{2}{*}{,054 } & \\
\hline & Male & 21 & 1,2917 & .57054 & & & & \\
\hline \multirow[t]{2}{*}{ Procedural Knowledge } & Female & 25 & ,7600 & ,37832 & \multirow{2}{*}{$-1,931$} & \multirow{2}{*}{44} & \multirow{2}{*}{, 060} & \\
\hline & Male & 21 & 1,0476 & ,62058 & & & & \\
\hline \multirow[t]{2}{*}{ Conditional Knowledge } & Female & 25 &,- 3520 & ,53003 & \multirow{2}{*}{,666 } & \multirow{2}{*}{44} & \multirow{2}{*}{,509 } & \\
\hline & Male & 21 &,- 4571 &, 53719 & & & & \\
\hline \multirow[t]{2}{*}{ Planning } & Female & 25 & ,3714 & 29451 & \multirow{2}{*}{$-2,008$} & \multirow{2}{*}{44} & \multirow{2}{*}{, 051} & \\
\hline & Male & 21 & .5714 & 38065 & & & & \\
\hline \multirow[t]{2}{*}{ Monitoring } & Female & 25 & 1,0700 & ,52177 & \multirow{2}{*}{$-1,182$} & \multirow{2}{*}{44} & \multirow{2}{*}{,243 } & \\
\hline & Male & 21 & 1,2560 & ,54267 & & & & \\
\hline \multirow[t]{2}{*}{ Information Management } & Female & 25 & ,5644 & 47890 & \multirow{2}{*}{,- 263} & \multirow{2}{*}{44} & \multirow{2}{*}{,794 } & \\
\hline & Male & 21 & ,5979 & ,36086 & & & & \\
\hline \multirow[t]{2}{*}{ Debugging } & Female & 25 &, 0800 & ,59161 & \multirow[b]{2}{*}{2,594} & \multirow[b]{2}{*}{44} & \multirow{2}{*}{, 013} & \multirow[t]{2}{*}{0,0776} \\
\hline & Male & 21 & -.3333 & 46619 & & & & \\
\hline Evaluation & Female & 25 &, 5400 & ,51433 & & & 126 & \\
\hline & Male & 21 & 6508 & 42461 &,$- / 81$ & 44 & ,436 & \\
\hline
\end{tabular}

Table 2 shows the gain scores, which obtained by subtracting the pre-test scores from the post-test scores. Table 2 indicates statistically significant differences between the Debugging gain scores and 
gender $[t(44)=2,594, p<.05]$. In all other sub-dimensions, there is no significant difference between the gain scores and gender. The existence of a statistically significant difference in the Debugging subdimension appears to have a small effect $\left(\eta^{2}=.0776\right)$. ANOVA results of the grade point averages of the PSTS' metacognitive awareness and its subscales for the pre- and post-test score differences are presented in Table 3.

Table 3. ANOVA results of the grade point averages of the PSTS' metacognitive awareness and its subscales for the post and pre-test score differences

\begin{tabular}{|c|c|c|c|c|c|c|}
\hline & Source of Variation & Sum of Squares & $\mathrm{Sd}$ & Mean Square & $\mathrm{F}$ & $\mathrm{p}$ \\
\hline \multirow{3}{*}{ Overall } & Between & ,083 & 3 & ,028 & ,310 & ,818 \\
\hline & Within & 3,738 & 42 & ,089 & & \\
\hline & Total & 3,821 & 45 & & & \\
\hline \multirow{3}{*}{ Declarative Knowledge } & Between & ,122 & 3 & 041 & ,174 & ,913 \\
\hline & Within & 9,794 & 42 & 233 & & \\
\hline & Total & 9,916 & 45 & & & \\
\hline \multirow{3}{*}{ Procedural Knowledge } & Between &, 529 & 3 & ,176 & ,641 & ,593 \\
\hline & Within & 11,552 & 42 & ,275 & & \\
\hline & Total & 12,082 & 45 & & & \\
\hline \multirow{3}{*}{$\begin{array}{l}\text { Conditional } \\
\text { Knowledge }\end{array}$} & Between & 450 & 3 & , 150 &, 516 & ,673 \\
\hline & Within & 12,190 & 42 & 290 & & \\
\hline & Total & 12,640 & 45 & & & \\
\hline \multirow{3}{*}{ Planning } & Between & ,122 & 3 & ,041 & ,322 &, 810 \\
\hline & Within & 5,314 & 42 & , 127 & & \\
\hline & Total & 5,436 & 45 & & & \\
\hline \multirow{3}{*}{ Monitoring } & Between & 1,341 & 3 & ,447 & 1,635 & , 196 \\
\hline & Within & 11,478 & 42 & ,273 & & \\
\hline & Total & 12,818 & 45 & & & \\
\hline \multirow{3}{*}{$\begin{array}{l}\text { Information } \\
\text { Management }\end{array}$} & Between & ,041 & 3 & ,014 & ,071 & ,975 \\
\hline & Within & 8,080 & 42 & 192 & & \\
\hline & Total & 8,121 & 45 & & & \\
\hline \multirow{3}{*}{ Debugging } & Between & ,778 & 3 & ,259 &, 782 &, 511 \\
\hline & Within & 13,919 & 42 & ,331 & & \\
\hline & Total & 14,697 & 45 & & & \\
\hline \multirow{3}{*}{ Evaluation } & Between & ,102 & 3 & ,034 & , 142 & ,934 \\
\hline & Within & 9,993 & 42 & 238 & & \\
\hline & Total & 10,095 & 45 & & & \\
\hline
\end{tabular}

When the ANOVA results in Table 3 examined, no significant difference was found among the groups for the overall metacognition and sub-dimensions scores. Furthermore, the t-test analysis between the mean scores of the PSTs' responses on metacognitive awareness and its sub-dimensions and their teaching experiences is presented in Table 4. 
Table 4. The t-test results for the mean scores of the PSTs' responses on metacognitive awareness and its subdimensions according to their experiences

\begin{tabular}{|c|c|c|c|c|c|c|c|}
\hline & Experience & $\mathrm{N}$ & Mean & Std. Deviation & $\mathrm{t}$ & df & Sig. (2-tailed) \\
\hline \multirow{2}{*}{ Overall } & Yes & 29 & 0,6160 & 0,30461 & \multirow{2}{*}{,347 } & \multirow{2}{*}{44} & \multirow{2}{*}{,730 } \\
\hline & No & 17 & 0,5848 & 0,27526 & & & \\
\hline \multirow{2}{*}{ Declarative Knowledge } & Yes & 29 & 1,1466 & 0,40925 & \multirow{2}{*}{,- 003} & \multirow{2}{*}{44} & \multirow{2}{*}{,997 } \\
\hline & No & 17 & 1,1471 & 0,57152 & & & \\
\hline \multirow[t]{2}{*}{ Procedural Knowledge } & Yes & 29 & 0,9052 & 0,55265 & \multirow{2}{*}{,235 } & \multirow{2}{*}{44} & \multirow{2}{*}{,816 } \\
\hline & No & 17 & 0,8676 & 0,46869 & & & \\
\hline \multirow[t]{2}{*}{ Conditional Knowledge } & Yes & 29 & $-0,3724$ & 0,55991 & \multirow{2}{*}{,457 } & \multirow{2}{*}{44} & \multirow{2}{*}{,650 } \\
\hline & No & 17 & $-0,4471$ & 0,48749 & & & \\
\hline \multirow[t]{2}{*}{ Planning } & Yes & 29 & 0,4729 & 0,37429 & \multirow{2}{*}{,257 } & \multirow{2}{*}{44} & \multirow{2}{*}{,799 } \\
\hline & No & 17 & 0,4454 & 0,30674 & & & \\
\hline \multirow[t]{2}{*}{ Monitoring } & Yes & 29 & 1,0991 & 0,45116 & \multirow{2}{*}{,- 924} & \multirow{2}{*}{44} & \multirow{2}{*}{,361 } \\
\hline & No & 17 & 1,2500 & 0,65551 & & & \\
\hline \multirow[t]{2}{*}{ Information Management } & Yes & 29 & 0,6092 & 0,43097 & \multirow{2}{*}{,611 } & \multirow{2}{*}{44} & \multirow{2}{*}{, 545} \\
\hline & No & 17 & 0,5294 & 0,42224 & & & \\
\hline \multirow[t]{2}{*}{ Debugging } & Yes & 29 & $-0,0414$ & 0,59613 & \multirow{2}{*}{1,045} & \multirow{2}{*}{44} & \multirow{2}{*}{,302 } \\
\hline & No & 17 & $-0,2235$ & 0,52384 & & & \\
\hline \multirow[t]{2}{*}{ Evaluation } & Yes & 29 & 0,6207 & 0,51926 & \multirow{2}{*}{,559 } & \multirow{2}{*}{44} & \multirow{2}{*}{, 579} \\
\hline & No & 17 & 0,5392 & 0,39321 & & & \\
\hline
\end{tabular}

When the t-test results in Table 4 are examined, it is seen that there is no statistically significant difference on overall scores between PSTs' with and without teaching experience.

\section{Discussion and Conclusions}

In this study, in a computer-assisted learning setting, the PSTs' development of metacognitive awareness and its sub-dimensions were examined on the geometric locus topic. The findings suggest that teaching geometric locus in this kind of a setting is generally effective. When the collected data examined, it appeared that there was not a statistically significant difference on the Debugging sub-dimension of metacognitive awareness in which the effect size was small. In the remaining sub-dimensions, the difference was statistically significant. When the metacognition literature is examined, it is seen that lessons thought by different computer applications precipitate using metacognitive skills before application (Gama, 2001; Hand, Wallace \& Yang, 2004; Howard et al., 2000; Vovides, 2005). As the PSTs perform their duties and responsibilities in the worksheets assigned to them, fulfilling the following processes may result in such a positive result: The process of predicting and discussing their estimates with the groupmates in the paper-pencil environment, modeling these estimates on the GeoGebra software screen, trying to decide on the results, trying to do the desired tasks together with the software, and trying to overcome the difficulties that arise in this process. The appearance of such a finding in the Debugging sub-dimension may have resulted from the PSTs not being able to fully use all the icons of the software. When the PSTs are able to fully use the icons, they can see their errors following the feedbacks provided by the software and this may increase the PSTs' desires to correct their mistakes. It is important to note that the PSTs are supposed to have metacognitive awareness and have to be equipped with adequate equipment to develop their metacognitive skills. Therefore, using such applications, which foreground PSTs' thinking throughout the whole teaching process, in classrooms may provoke positive results.

When the gain scores, which were obtained by subtracting the pre-test scores from the post test scores of the metacognitive awareness scale, were examined, a statistically significant difference was found in the Debugging sub-dimension according to the gender. In all other sub-dimensions, there was no significant difference in relation to the gender. The effect size of this difference in the Debugging subdimension was small. With the appearance of such finding, one can say that girls were cognitively more resourceful than boys on strategies, such as correcting mistakes, in relation to the geometric locus concept. Similarly, Bağçeci, Döş and Sarica (2011) and Kana (2015) found that in the Debugging subdimension of metacognitive awareness, girls were more aware of and willing to correct their mistakes than boys during the instruction. In addition, Deniz, Dansız, Akgün and İşlayan (2014) found that female 
PSTs had higher levels of metacognitive awareness than male PSTs. Furthermore, studies show that gender differences in metacognition may be due to two important factors: social and biological differences (Kimmel, 2000, Lowe, Mayfield \& Reynold, 2003).

When the gain scores obtained by subtracting the pre-test scores from the post-test scores of the metacognitive awareness scale were examined, it was seen that there was no significant difference between the groups in the overall metacognitive awareness score and its sub-dimensions according to the PSTs' academic grade averages. Tok, Özgan and Döş (2010) and Kana (2015) stated a statistically significant difference only between the academic grade averages and Evaluation sub-dimension of the Metacognitive Awareness Inventory. In this study, nonexistence of a significant difference between the academic grade averages and Evaluation sub-dimension can be rested on the PSTs' always taking part in the teaching process during the GeoGebra practices. In this process, the PSTs worked in groups of two and predicted the geometrical locuss assigned to them. Next, they tried to explain their predictions in the paper-pencil setting. Later, the PSTs attempted to find the geometrical locuss on the GeoGebra software that enabled them to compare their answers with previous paper-pencil predictions. This situation can be interpreted as one of the best examples of PSTs being in constant collaboration with the GeoGebra software. When the t-test results that explained the relationship between the scores obtained from Metacognitive Awareness Inventory and its sub-dimensions with the results obtained by subtracting the pre-test scores from the post-test scores are examined, it is seen that there is no statistically significant difference between the PSTs' overall metacognitive scores and the scores obtained from sub-dimensions of the inventory. This result appears to be normal since the PSTs did not have enough chance to complete their experiences with GeoGebra. The PSTs' development of metacognitive awareness can be achieved by offering teaching practice courses from the first year of the undergraduate programs, which is the starting point of the teaching profession, and these courses should continue throughout their education programs.

\section{References}

[1] Akın, A., Abacı, R., \& Çetin, B. (2007). The validity and reliability study of the Turkish version of the Metacognitive Awareness Inventory. Educational Science: Theory \& Practice, 7(2), 655-680.

[2] Bağçeci, B., Döş, B., \& Sarıca, R. (2011). İlköğretim öğrencilerinin üstbilişsel farkındalık düzeyleri ile akademik başarı arasındaki ilişkinin incelenmesi. Mustafa Kemal Üniversitesi Sosyal Bilimler Enstitüsü Dergisi, 8(16), 551-566.

[3] Baki, A., Çekmez, E., \& Kösa, T. (2009, July). Solving geometrical locus problems in GeoGebra. Presented at the GeoGebra Conference, RISC in Hagenberg.

[4] Baltaci, S. (2014). Dinamik matematik yaziliminin geometrik yer kavraminin ogretiminde kullanilmasinin baglamsal ogrenme boyutundan incelenmesi [An investigation of the use of dynamic mathematics software in teaching the concept of locus in terms of contextual learning] (unpublished doctoral thesis). Karadeniz Teknik University, Trabzon, Turkey.

[5] Baltaci, S., \& Baki, A. (2016). Dinamik matematik yazılımının öteleme ve dönme dönüşümlerinin öğretiminde kullanılmasının bağlamsal öğrenme boyutundan incelenmesi, Ondokuz Mayls Üniversitesi Ĕgitim Fakültesi Dergisi, 35(1), 163-183.

[6] Baltacı, S., Yıldız, A., \& Kösa, T. (2015). Analitik geometri öğretiminde GeoGebra yazılımının potansiyeli: Öğretmen adaylarının görüşleri. Türk Bilgisayar ve Matematik Eğitimi Dergisi (TÜRKBİLMAT), 6(3), 483-505.

[7] Baltaci, S., Yildiz, A., \& Özcakir, B. (2016). The relationship between metacognitive awareness levels, learning styles, genders and mathematics grades of fifth graders. Journal of Education and Learning, 5(4), 78-89.

[8] Blank, L.M. (2000). A metacognitive learning cycle: A better warranty for student understanding? Science Education, 84, 486-506. 
[9] Botana, F., \& Valcarce, J. L. (2003). A software tool for the investigation of plane loci. Mathematics and Computers in Simulation, 61, 139-152.

[10] Cha, S., \& Noss, R. (2001). Investigating students' understanding of locus with dynamic geometry. Proceedings of the British Society for Research into Learning Mathematics, 21(3), 8489.

[11] Cha, S., \& Noss, R. (2004). Investigating students understanding of locus with dynamic geometry. [Online] Retrieved February 10, 2017, from http://koreansociety.ioe.ac.uk/article/17.pdf.

[12] Çakıroğlu, A. (2007). Üstbilişsel strateji kullanımının okuduğunu anlama düzeyi düşük ögrencilerde erişi artırımına etkisi (Yayınlanmamış doktora tezi). Gazi Üniversitesi Eğitim Bilimleri Enstitüsü, Ankara.

[13] Deniz, D., Küçük, B., Cansız, Ş., Akgün, L., \& İşleyen, T. (2014). Ortaöğretim matematik öğretmeni adaylarının üstbiliş farkındalıklarının bazı değişkenler açısından incelenmesi. Kastamonu Eğitim Dergisi, 22(1), 305-320.

[14] Deseote, A., Roeyers H., \& Buysse, A. (2001). Metacognition and mathematical problem solving in grade 3. Journal of Learning Disabilities, 34(5), 435-449.

[15] Dikovich, Lj. (2009). Applications GeoGebra into teaching some topics of mathematics at the college level. Retrieved February 15, 2017 from http://www.doiserbia.nb.rs/img/doi/18200214/2009/1820-02140902191D.pdf.

[16] Doğan, A. (2013). Üstbiliş ve üstbilişe dayalı öğretim. Middle Eastern \& African Journal of Educational Research, 3, 6-20.

[17] Douville P., \& Pugalee, D. K. (2003, September). Investigating the relationship between mental imaging and mathematical problem solving. The Mathematics Education into the 21st Century Project, Proceedings of the International Conference. The Decidable and the Undecidable in Mathematics Education. Brno, Czech Republic.

[18] Everson, H. T., \& Tobias, S. (1998). The ability to estimate knowledge and performance in college: A metacognitive analysis. Instructional Science, 26, 65-79.

[19] Flavell, J. H. (1998). The development of children's knowledge about mind. New York: In J. W. Astington, $\mathrm{P}$.

[20] Flavell, J. H. (1979). Metacognition and cognitive monitoring: A new area of cognitivedevelopmental inquiry. American psychologist, 34(10), 906-911.

[21] Frank, B. A. (2010). Conjecturing in dynamic geometry: A model for conjecture-generation through maintaining dragging (Unpublished doctoral dissertation). University of New Hampshire, Durham.

[22] Gama, C. (2001). Investigating the effects of training in metacognition in an interactive learning environment: Design of an empirical study. In B. Zayas and C. Gama (Eds.), Proceedings of the 5th Human Centred Technology Postgraduate Workshop. Brighton, UK: University of SussexCognitive Science Research Paper 538.

[23] Garner, R. (1987). Metacognition and Reading Comprehension. Norwood, NJ: Ablex.

[24] Gorghiu, G., Puana, N., \& Gorghiu L. M. (2009). Solving geometrical locus problems using dynamic interactive geometry applications.Retrieved January 18, 2014, from http://www.formatex.org/micte2009/book/814818.pdf.

[25] Gunstone, R.F., \& Mitchell, I.J. (1998). Metacognition and conceptual change. In J.J. Mintzes, J.H. Wandersee \& J.D. Novak (Editörler) Teaching Science for Understanding: A Human Constructivist View (133-163). San Diego: Academic Press.

[26] Gülkılık, H. (2008). Öğretmen adaylarının bazı geometrik kavramlarla ilgili sahip oldukları kavram imajlarının ve imaj gelişiminin incelenmesi üzerine fenomenografik bir çalışma [Aphenomenographic study on the concept images and amge development of prospective 
secondary mathematics teachers related with some geometric concepts] (Unpublished Master Thesis). Gazi University, Ankara, Turkey.

[27] Güven, B. (2002). Dinamik geometri yazılımı Cabri ile keşfederek geometri öğrenme [Exploratory geomety learning within cabri-based environment] (Unpublished Master Thesis). Karadeniz Technic University, Trabzon, Turkey.

[28] Güven, B. (2008). Using dynamic geometry software to gain insight into a proof. International Journal Computer Mathematics Learning, 13, 251-262.

[29] Güven, B., \& Karataş, İ. (2009). Dinamik geometri yazılımı Cabri'nin ilköğretim matematik öğretmen adaylarının geometrik yer problemlerindeki başarılarına etkisi [The effect of dynamic geometry software (Cabri) on pre-service elemantary mathematics teachers' achievement about locus problems]. Ankara University Journal of Educational Sciences, 42(1), 1-31.

[30] Hacker, D. J. (1998). "Metacognition: Definitions and Empirical Foundations". In D. J. Hacker, A. Graesser and J. Dunlosky (Eds.). Metacognition in Educational Theory and Practice (pp.123). Mahwah, NJ: Lawrence Erlbaum.

[31] Hall, K., \& Myers, J. (1998). 'That's just the way I am': Metacognition, personal intelligence and reading. Journal of Research in Reading, 32(2), 8-13.

[32] Hand, B., Wallace, C., \& Yang, E. (2004). Using the science writing heuristic to enhance learning outcomes from laboratory activities in seventh grade science: Quantitative and qualitative aspects. International Journal of Science Education, 26 (2), 131-149.

[33] Hazzan, O., \& Goldenberg, E. P. (1997). Students' understanding of the notion of function in dynamic geometry environments. International Journal of Computers for Mathematical Learning, 1, 263-291.

[34] Hohenwarter, M., \& Jones, K. (2007). Ways of linking geometry and algebra: the case of GeoGebra. Proceedings of British Society for Research into Learning Mathematics, 27(3), 126131.

[35] Howard, B. C., McGee, S., Hong, N.S. \& Shia, R. (April, 2000). The influence of metacognitive self-regulation and ability levels on problem solving. Paper presented at the annual meeting of the American Educational Research Association. New Orleans, LA.

[36] Jahn, A. P. (2002). Locus" and "Trace" in Cabri géomètre: relationships between geometric and functional aspects in a study of transformations. Zentralblatt für Didaktik der Mathematik (ZDM), 34(3), 78-84.

[37] Jones, M. G., Farquhar, J. D. and Surry, D. W. (1995). Using Metacognitive Theories to Design User Interfaces for Computer-Based Learning. Educational Technology, 35, 12-22.

[38] Kana, F. (2015). Türkçe öğretmeni adaylarının üstbiliş farkındalık düzeyleri [Metacognitive avareness levels of Turkish language preservice teachers]. The Journal of Academic Social Science, 3(17), 66-81.

[39] Karakelle, S., \& Saraç, S. (2007). Çocuklar için üstbilişsel farkındalık ölçeği (ÜBFÖ-Ç) A ve B formları: Geçerlik ve güvenirlik çalışmaları [Validity and Factor Structure of Turkish Versions of The Metacognitive Awareness Inventory for Children (Jr. MAI) - A and B Forms]. Turkish Pyschological Articles, 10 (20), 87-103.

[40] Kimmel, M.S. (2000). The Gender Society. Oxford University press.

[41] Lowe, P.A., Mayfield, J.W., \& Reynold, C.R. (2003). Gender differences in memory test performance among children and adolescent. Archives of Clinical Neuropsychology, 18, 865-878.

[42] Kramarski, B. (2008). Promoting teachers' algebraic reasoning and self-regulation with metacognitive guidence. Metacognition Learning, 3, 83-99. 
[43] Kramarski, B., \& Mevarech, Z. R. (2003). Enhancing mathematical reasoning in the classroom: The effect of cooperative learning and metacognitive training. American Educational Research Journal, 40, 281-310.

[44] Kramarski, B., Zemira, R. M., \& Arami, M. (2002). The effects of metacognitive instruction on solving mathematical authentic tasks. Educational Studies in Mathematics, 49, 225-250.

[45] Kuiper, R. (2002). Enhancing metacognition throught the reflective use of self-regulated learning strategies. The Journal of Continuing Education in Nursing, 33(2), 78-87.

[46] Kutluca, T., \& Zengin, Y. (2011). Matematik öğretiminde GeoGebra kullanımı hakkında öğrenci görüşlerinin değerlendirilmesi [Evaluation of views of students about using GeoGebra in teaching of mathematics]. Dicle University Journal of Ziya Gökalp Education Faculty, 17,160-172.

[47] Küçük-Özcan, Z. Ç. (2000). Teaching metacognitive strategies to 6th grade students (Unpublished B.S. thesis). İstanbul: Boğaziçi University, The Institute of Science and Engineering.

[48] Lucangeli, D., \& Cesare Cornoldi (1997). Mathematics and metacognition: what is the nature of relationship? Mathematical Cognition, 3, 121-139.

[49] Mckay, M. A (1999). A Comparison of the Effects of Procedural and Metacognition Instruction on the Transfer of Computer Software Skills (Unpublished doctoral dissertation). Norman, OK: University of Oklahoma.

[50] Olive, J. (2002). Implications of using dynamic geometry technology for teaching and learning. In: M. Saraiva, J. Matos, I. Coelho (Eds.), Ensino e Aprendizagem de Geometria (pp. 300-321). Lisbon: SPCE.

[51] Palincsar, A. S. (1986). Metacognitive strategy instruction. Exceptional Children, 53(2), 118 124.

[52] Paris, S. G. and Winogard, P. (1990). How metacognition can promote academic learning and instruction. In B. F. Jones and L. Idol (Eds.), Dimensions of Thinking and Cognitive Instruction (pp.15-51). Hillsdale, NJ: Lawrence Erlbaum.

[53] Pekdemir, Ü. (2004). Dinamik geometri yazılımı Cabri'nin geometrik yer konusunda öğrenci başarlst üzerindeki etkisi [The effect of dynamic geometry software Cabri on students' success on locus] (Unpublished master thesis). Karadeniz Technical University, Trabzon, Turkey.

[54] Real, F. L., \& Leung, A. (2006). Dragging as a conceptual tool in dynamic geometry environments. International Journal of Mathematical Education in Science and Technology, 37(6), 665-679.

[55] Schoenfeld, A. (1987). What's all the fuss about metacognition? In: A. H. Schoenfeld (Ed.), Cognitive Science and Mathematics Education, 189-215. Lawrence Erlbaum.

[56] Schraw, G., \& Sperling-Dennison, R. (1994). Assessing metacognitive awareness. Contemporary Educational Psychology, 19, 460-470.

[57] Schumann, H., \& Green, D. (2001). A Computer based method for exploring functional relations in geometric figures. Teaching Mathematic and Its Applications, 20, 145-155.

[58] Schunk, D. H. (1989). Self-efficacy and achievement behaviors. Educational Psychology Review, 1,173-208.

[59] Senemoğlu, N. (1997). Gelisim, Ögrenme ve Ögretim [Development, Learning and Teaching]. Ankara: Özsen Matbaacıllk Ltd Sti.

[60] Smith, E. M., Ford, J. K., \& Kozlowski, S. W. J. (1997). Building adaptive expertise: Implications for training design strategies. Training for a Rapidly Changing Workplace. Washington, DC: American Psychological Association (pp.89-118). 
[61] Şen, Ş. H. (2012). Ortaöğretim öğrencilerinin bilişüstü yetileri kullanma durumlarının bazı değişkenler açısından incelenmesi [Examiniation of secondary school students' use of abstinence ability in terms of some variables]. Journal of Educational and Instructional Studies in the World, 2(1), 2146-7463.

[62] Tok, H., Özgan, H., \& Döş, B. (2010). Assessing metacognitive awareness and learning strategies as positive predictors for success in a distance learning class. Mustafa Kemal Üniversitesi Sosyal Bilimler Enstitüsü Dergisi, 7(14), 123-134.

[63] Toney, R. J. (2000). An investigation of learner control and metacognition using a web-based training program (Unpublished doctoral dissertation). East Lansing, MI: Michigan State University.

[64] Tunca, N., \& Alkın-Şahin, S (2014). Öğretmen adaylarının bilişötesi (Üst Biliş) öğrenme strtaejileri ile akademik öz yeterlilik inançları arasındaki ilişki. Anadolu Journal of Educational Sciences International, 4(1), 47-56.

[65] Volet, S. E. (1991). Modeling and coaching of relevant metacognitive strategies for enhancing university students' learning. Learning and Instruction, 1(4), 319-336.

[66] Yıldırım, S. (2010). Üniversite ögrencilerinin bilişötesi farkındalıkları ile benzer matematiksel problem türlerini çözmeleri arasındaki ilişsi (Yayınlanmamış Yüksek Lisans Tezi). Gazi Osmanpaşa Üniversitesi Sosyal Bilimler Enstitüsü, Tokat.

[67] Yildiz, A., Baltaci, S., \& Güven, B. (2011). Metacognitive behaviours of the eighth grade gift ed students in problem solving process. The New Educational Review, 26 (4), 248-260.

[68] Yıldız, F. E., \& Ergin, Ö. (2012). 5E öğrenme modelinin kullanıldığı öğretimin yedinci sınıf ögrencilerinin üst bilişlerine etkisi [The effect of $5 \mathrm{E}$ learning model instruction on seventh grade students' metacognitive process]. Türk Fen Eğitimi Dergisi, 9 (3), 55-77.

[69] Victor, A. M. (2004). The effects of metacognitive instruction on the planning and academic achievement of first grade and second grade children (Yayınlanmamış doktora tezi). Illinois Institute of Technology, 23.02.2005 tarihinde ProQuest Digital Dissertations tan alınmıştır.

[70] Vovides, Y. (2005). Investigating learning from hypermedia via the implementation of a computer-based metacognition training regimen and a hypermedia program (Unpublished doctoral dissertation). Iowa City, IA: The University of Iowa.

[71] Welton, A. D., \& Mallan, J. T. (1999). Children and Their World. Strategies for Teaching, H. Mifflin Company, USA.

\section{Author}

Serdal Baltaci, Assist. Prof. Dr., Kırşehir Ahi Evran University, Faculty of Education, the Department of Mathematics Education, Kırşehir, Turkey, e-mail: serdalbaltaci@gmail.com 